\title{
PW02-019 - Inflammatory pathways activation in TRAPS patients
}

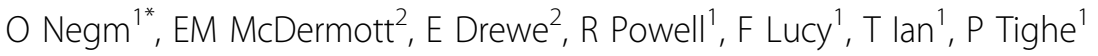 \\ From 7th Congress of International Society of Systemic Auto-Inflammatory Diseases (ISSAID) \\ Lausanne, Switerland. 22-26 May 2013
}

\section{Introduction}

Mutations in TNFRSF1A can result in the autosomal dominant TNF receptor-associated periodic syndrome

(TRAPS): a complex and heterogeneous systemic autoinflammatory disorder. Misfolding, intracellular aggregation and ligand-independent signalling by mutant TNFR1 play central roles in disease pathophysiology.

\section{Objectives}

This work was conducted to study the intracellular signalling pathway activation elicited by mutant TNFR1.

\section{Methods}

To understand the complexity of intracellular signalling pathway perturbation in TRAPS, a prototypic mutant TNFR1 (C33Y), or wild-type TNFR1 (WT), were expressed at near physiological levels in an SK-Hep-1 cell model system. TNFR1-associated signalling pathway intermediates were examined under a range of conditions, employing reverse-phase protein microarray. Peripheral blood mononuclear cells (PBMC) from C33Y TRAPS patients and matched healthy controls were similarly examined. amplifier" positive feedback loop that promotes and sustains a proinflammatory state.

\section{Conclusion}

The study thus reveals the pleiotropic effect of a TRAPSassociated mutant form of TNFR1 on multiple inflammatory signalling pathways.

\section{Disclosure of interest}

None declared.

\section{Authors' details}

${ }^{1}$ Immunology, School of Molecular Medical Sciences, University of Nottingham, UK. ${ }^{2}$ Nottingham University Hospitals, National Health Service Trust, Nottingham, UK.

Published: 8 November 2013

doi:10.1186/1546-0096-11-S1-A159

Cite this article as: Negm et al:: PW02-019 - Inflammatory pathways activation in TRAPS patients. Pediatric Rheumatology 2013 11(Suppl 1):A159.

\section{Results}

In comparison to cells expressing WT TNFR1 alone, expression of C33Y-TNFR1 in SK-Hep-1 cells and TRAPS patients' PBMCs revealed a subtle up-regulation of a wide spectrum of signalling intermediates and their phosphorylated forms. These were associated with a proinflammatory/ anti-apoptotic phenotype, including NF-k B, p38, MEK/ERK and JNK MAP kinase pathways, Phosphoinositide 3 kinase, STAT3, JAK2/c-Src, Gsk-3 $\beta$ and transcription factors (including ATF, Elk, Jun). Increased activated Jak2/STAT3 may contribute to an "IL6

'Immunology, School of Molecular Medical Sciences, University of Nottingham, UK

Full list of author information is available at the end of the article

Submit your next manuscript to BioMed Central and take full advantage of:

- Convenient online submission

- Thorough peer review

- No space constraints or color figure charges

- Immediate publication on acceptance

- Inclusion in PubMed, CAS, Scopus and Google Scholar

- Research which is freely available for redistribution
() Biomed Central

\section{Biomed Central}

